\title{
Physiology of the production of strawberries inoculated with arbuscular mycorrhizal fungi
}

\section{Fisiologia da produção de morangueiros inoculados com fungos micorrízicos arbusculares}

\author{
Ely Cristina Negrelli Cordeiro ${ }^{1 *}$; Juliano Tadeu Vilela de Resende ${ }^{2}$; Orivaldo José \\ Saggin Júnior ${ }^{3}$; Daniele Aparecida Nascimento ${ }^{4}$; André Ricardo Zeist ${ }^{5}$; Renata \\ Favaro $^{6}$; Katielle Rosalva Voncik Córdova ${ }^{7}$; André Gabriel ${ }^{8}$
}

\begin{abstract}
The use of arbuscular mycorrhizal fungi (AMF) is a strategy to increase the absorption of nutrients by plants, stimulate the plant defense system, and promote the synthesis of bioactive compounds. In addition, AMF can reduce production costs and improve the agricultural and environmental sustainability of farming systems. The objective of this study is to evaluate the effect of AMF on production and physiological parameters of strawberry cultivars. The cultivars Camarosa, Aromas, Camino Real, Monterrey, Portola, San Andreas, and Albion were evaluated in the year 2016, and Camarosa, Camino Real, Monterrey, and Albion were analyzed in the year 2017. These cultivars were grown either with or without AMF. The analyzed production variables were the total number of fruits and fruit yield and weight. Gas exchange and leaf area were also determined in 2017. Fruit yield in treated and control plants was assessed in the two study years. AMF inoculation augmented the leaf area in all cultivars except for Monterrey, photosynthetic performance in the cultivars Camarosa and Camino Real, and the transpiration rate in the cultivar Camarosa. These results indicate that AMF improve agronomic and physiological characteristics of strawberry cultivars.
\end{abstract}

Key words: Fragaria $x$ ananassa Duch. Mycorrhizae. Inoculants. Physiological characteristics. Rhizospheric microorganisms.

\footnotetext{
1 Discente de Doutorado, Programa de Pós-Graduação em Agronomia/Produção Vegetal, Universidade Federal do Paraná, UFPR, Curitiba, PR, Brasil. E-mail: elycordeiro@outlook.com

2 Prof., Departamento de Agronomia e do Programa de Pós-Graduação em Agronomia, PGAGRO, UEL, Londrina, PR, Brasil. E-mail: jvresende@uol.com.br

3 Pesquisador, Empresa Brasileira de Pesquisa e Agropecuária, EMBRAPA, Agrobiologia e Prof., Programa de Pós-Graduação em Agronomia-Ciência do solo, UFRRJ, Seropédica, RJ, Brasil. E-mail: orivaldo.saggin@embrapa.br

4 Discente de Mestrado, Programa de Pós-Graduação em Agronomia/Produção Vegetal, Universidade Estadual do Centro Oeste, UNICENTRO, Guarapuava, PR, Brasil. E-mail: dani123nas@gmail.com

5 Prof., Curso de Agronomia da Universidade do Oeste Paulista, UNOESTE, Presidente Prudente, SP, Brasil. E-mail: andre.zeist@, bol.com.br

6 Discente de Doutorado, Programa de Pós-Graduação em Agronomia/Produção Vegetal, UNICENTRO, Guarapuava, PR, Brasil. E-mail: renatafavaroo@yahoo.com.br

7 Prof ${ }^{a}$, Departamento de Engenharia de Alimentos, UNICENTRO, Guarapuava, PR, Brasil. E-mail:kvcordova@hotmail.com

8 Discente de Doutorado, Programa de Pós-Graduação em Agronomia/Produção Vegetal, UNICENTRO, Guarapuava, PR, Brasil. E-mail: andre.gb85@hotmail.com

* Author for correspondence
} 


\section{Resumo}

O uso de fungos micorrízicos arbusculares (FMAs) é uma alternativa para proporcionar melhor absorção de nutrientes, estimular o sistema de defesa dos vegetais e promover a síntese de compostos bioativos. Além disso, podem diminuir os custos de produção e tornar os sistemas de cultivo mais sustentáveis e comprometidos com o ambiente. Objetivou-se com o presente trabalho avaliar a influência de FMAs nos componentes agronômicos e fisiológicos de cultivares de morangueiro. As cultivares avaliadas foram Camarosa, Aromas, Camino Real, Monterrey, Portola, San Andreas e Albion no ano de 2016 e Camarosa, Camino Real, Monterrey e Albion no ano de 2017, inoculadas e não inoculadas com FMAs. Avaliou-se os componentes agronômicos (número de frutos, produção total e massa de frutos) nos dois anos de cultivo. No ano de 2017 avaliou-se também as trocas gasosas e estimou-se a área foliar. Quanto aos componentes agronômicos, houve destaque para as plantas micorrizadas em relação às não micorrizadas nos dois anos de avaliação. A inoculação com FMAs proporcionou incremento da área foliar para as cultivares, exceto Monterrey. Os FMAs proporcionaram ainda incremento do rendimento fotossintético para as cultivares Camarosa e Camino Real e da transpiração para Camarosa. O uso de FMAs proporcionou melhora das características agronômicas e fisiológicas das cultivares de morangueiro avaliadas no presente trabalho.

Palavras-chave: Fragaria $x$ ananassa Duch. Micorrizas. Inoculantes. Componentes fisiológicos. Microorganismos rizosféricos.

\section{Introduction}

Strawberries (Fragaria $x$ ananassa Duch.) are cultivated in different regions of the world. In the year 2014, the global production of strawberries was more than 8 million tons in approximately 373,000 hectares. The largest producers were China, with more than 3 million tons, and the United States, with approximately 1.3 million tons (FAO, 2014). Strawberry production in Brazil is approximately 105,000 tons in an area of 4,000 ha (REISSER JÚNIOR et al., 2015).

Strawberry is a perennial crop that requires extensive labor and is cultivated primarily by small farmers. For this reason, this crop has significant economic and social importance and is a relevant source of income for family farming. Conventional strawberry cultivation has become costly because of the indiscriminate use of crop protection products and fertilizers to increase yield (GIMÉNEZ et al., 2008). The extensive and often unnecessary use of fertilizers leads to imbalances in the crop system, enhancing plant susceptibility to pests and pathogens, and potentially leading to soil salinization and environmental pollution (KIRSCHBAUM, 2006).
Mycorrhizae is a symbiotic association between plant roots and the beneficial fungi of the soil, and arbuscular mycorrhizal fungi (AMF) are a promising strategy to minimize the indiscriminate use of mineral fertilizers and augment the yield and quality of several crops, including strawberries (VESTBERB et al., 2004).

The use of AMF in crop production systems has intensified because mycorrhizal colonization can stimulate the plant defense system and tolerance to biotic and abiotic stresses (SAGGIN JÚNIOR; SILVA, 2005; VOS et al., 2012; CECATTO, 2016). The use of this symbiotic system can reduce the use of fertilizers in plants by enhancing the efficiency of absorption of nutrients with low soil mobility, such as phosphorus (COSCOLIN, 2016). Moreover, AMF may act as bioregulators, increasing plant hormonal balance, tolerance to pathogens (ROUPHAEL et al., 2015), biomass, development, and yield (ANTUNES et al., 2012).

It has been shown that inoculation of strawberries with AMF improves plant growth (NIEMI; VESTBERG, 1992), stolon emission (ALARCÓN et al., 2000), photosynthetic performance, fruit yield (BORKOWSKA, 2002), tolerance to pathogens 
(MATSUBARA et al., 2009; VOS et al., 2012), and water stress (BOROWICZ, 2010). However, few studies to date evaluated the effect of AMF on the physiology of production of strawberry cultivars grown under field conditions under low tunnels. The objective of this study is to assess the effect of AMF on production and physiological characteristics of strawberry cultivars.

\section{Materials and Methods}

The study was conducted at the Olericulture Sector and the Laboratory of Plant Physiology/ Horticulture of the Research Center for Vegetables (Núcleo de Pesquisa em Hortaliças-NPH), at the Department of Agronomy, Cedeteg campus of the State University of Center-West (Universidade Estadual do Centro-Oeste-UNICENTRO), located in Guarapuava (latitude, $25^{\circ} 23^{\prime} 01^{\prime \prime} \mathrm{S}$; longitude, $51^{\circ} 29^{\prime} 50^{\prime \prime} \mathrm{W}$; altitude of 1,025 meters), Paraná, Brazil. The soil is classified as Typical Dystrophic Bruno Latosol (EMBRAPA, 2013).

The study used a completely randomized block design. In 2016, a $2 \times 7$ factorial arrangement was chosen, with four blocks, totaling 14 treatments comprised of seven strawberry cultivars (five with a neutral photoperiod [Aromas, Monterey, Portola, San Andreas, and Albion] and two with a short photoperiod [Camarosa and Camino Real] inoculated or not with AMF). In the year 2017, a 2 $\times 4$ factorial arrangement was used, with six blocks, totaling eight treatments comprised of four cultivars (Monterey, Albion, Camarosa, and Camino Real) treated or not with AMF. In both years, each block corresponded to one plot, and each plot contained eight plants cultivated in an area of $30 \times 30 \mathrm{~cm}$.

The commercial seedlings used were imported from Chile, certified, and disease-free. The soil was prepared by plowing, liming, and harrowing. The seedbeds were covered with a black polyethylene $30-\mu \mathrm{m}$ film (mulching). Fertilization at planting was performed before transplanting according to the soil characteristics of the study area.
Liming was carried out in 2016 two months before planting using $100 \mathrm{~g}$ of calcitic limestone per $\mathrm{m}^{2}$. Fertilization at planting consisted of $50 \mathrm{~g}$ of $\mathrm{K}_{2} \mathrm{O}$ and $50 \mathrm{~g}$ of nitrogen per $\mathrm{m}^{2}$. Phosphate fertilization was performed using $50 \%$ of the recommended dose with $200 \mathrm{~g}$ of $\mathrm{P}_{2} \mathrm{O}_{5}$ at planting and topdressing. This type of fertilization was used to stimulate the development of mycorrhizal fungi, which are more active under conditions of low phosphorus availability in the soil (Smith and Read, 2008).

In $2017,384 \mathrm{~g}$ of calcitic limestone per $\mathrm{m}^{2}$ was applied to the soil. Fertilization at planting consisted of $50 \mathrm{~g} \mathrm{~K}_{2} \mathrm{O}$ and $48.24 \mathrm{~g}$ nitrogen per $\mathrm{m}^{2}$. Phosphate fertilization was performed with $50 \%$ of the recommended dose with $253 \mathrm{~g}$ of $\mathrm{P}_{2} \mathrm{O}_{5}$ per $\mathrm{m}^{2}$. Micronutrients were sprayed every 15 days, including $0.7 \mathrm{~g}$ of Borax, $0.3 \mathrm{~g}$ of copper hydroxide, $1.8 \mathrm{~g}$ of zinc sulfate, and $2.9 \mathrm{~g}$ of CAB Plus per $\mathrm{m}^{2}$.

Before seedling planting, a mycorrhizal inoculant containing several AMF strains was added to the pits as detailed in Tables 1 and 2. The inoculant was supplied by the Johanna Döbereiner Biological Resource Center (Centro de Recursos Biológicos Johanna Döbereiner) of Embrapa Agrobiology, located in Seropédica, Rio de Janeiro, Brazil.

The management of pests and diseases was carried out during the crop cycle as needed, and specific products licensed for use in strawberry crops in Paraná were used. The alternate spraying of the active ingredients thiamethoxam (250 g $\left.\mathrm{kg}^{-1}\right)$ and abamectin $\left(18 \mathrm{~g} \mathrm{~L}^{-1}\right)$ was performed for controlling mites and aphids. Rovral ${ }^{\circledR}\left(500 \mathrm{~g} \mathrm{~L}^{-1}\right)$, Bendazol $^{\circledR}\left(700{\left.\text { g } 1000 ~ L^{-1}\right) \text {, and Difenoconazole }}^{\circledR}\right.$ (200 $\left.\mathrm{g} \mathrm{L}^{-1}\right)$ were used for the preventive control of fungal diseases, including Mycosphaerella fragaria, anthracnose, and gray mold.

Irrigation was performed by dripping according to the water requirement of the crop and climatic conditions. The fruits were harvested every two days from August to February in the two study years. Fruits with more than $3 / 4$ reddish color were collected. 
Fruits with a weight higher than 10 grams were considered commercial, and those with injuries in the epidermis were discarded. The following production variables were evaluated: number of commercial fruits per plant (NCFP), number of non-commercial fruits per plant (NNCFP), and total number of fruits per plant (TNFP), commercial fruit yield (g/plant) (CFY), non-commercial fruit yield (g) (NCFY), total fruit yield (TFY), and mean weight of commercial fruits per plant (g) (MWCFP).

Table 1. Arbuscular mycorrhizal fungi strains inoculated in strawberry crops in 2016.

\begin{tabular}{|c|c|c|c|c|c|}
\hline Strain & $\begin{array}{c}\text { Original } \\
\text { code }\end{array}$ & Species & $\begin{array}{l}\text { Num- } \\
\text { ber of } \\
\text { spores/g }\end{array}$ & $\begin{array}{l}\text { Number of } \\
\text { spores per dose } \\
\text { of inoculant }\end{array}$ & $\begin{array}{l}\text { Weight of } \\
\text { the inocu- } \\
\text { lant dose } \\
\quad \text { (g) }\end{array}$ \\
\hline A97 & CNPAB 053 & $\begin{array}{l}\text { Acaulospora colombiana (Spain \& N.C. } \\
\text { Schenck) Kaonongbua, J.B. Morton \& } \\
\text { Bever (2010) }\end{array}$ & 18 & 10 & 0.56 \\
\hline A96 & CNPAB 052 & $\begin{array}{l}\text { Acaulospora morrowiae Spain \& N.C. } \\
\text { Schenck (1984) }\end{array}$ & 23 & 10 & 0.43 \\
\hline A38 & IES-33 & Acaulospora scrobiculata Trappe (1977) & 43 & 10 & 0.23 \\
\hline A2 & CNPAB 002 & $\begin{array}{l}\text { Dentiscutata heterogama (T.H. Nicolson } \\
\text { \& Gerd.) Sieverd., F.A. Souza \& Oehl } \\
\text { (2008) }\end{array}$ & 27 & 10 & 0.37 \\
\hline A36 & IES-29 & $\begin{array}{l}\text { Gigaspora candida Bhattacharjee, } \\
\text { Mukerji, J.P. Tewari \& Skoropad (1982) }\end{array}$ & 6 & 10 & 1.67 \\
\hline A20 & CNPAB 020 & $\begin{array}{l}\text { Glomus formosanum C.G. Wu \& Z.C. } \\
\text { Chen (1986) }\end{array}$ & 25 & 10 & 0.40 \\
\hline $\mathbf{A 8 0}$ & CNPAB 038 & $\begin{array}{l}\text { Scutellospora calospora (T.H. Nicolson } \\
\text { \& Gerd.) C. Walker \& F.E. Sanders } \\
(1986)\end{array}$ & 15 & 10 & 0.67 \\
\hline A75 & CNPAB 034 & $\begin{array}{l}\text { Scutellospora gilmorei (Trappe \& } \\
\text { Gerd.) C. Walker \& F.E. Sanders (1986) }\end{array}$ & 8 & 10 & 1.25 \\
\hline & & Inoculant mixture & 14 & 80 & 5.58 \\
\hline
\end{tabular}

Table 2. Arbuscular mycorrhizal fungi strains inoculated in strawberry crops in the year 2017.

\begin{tabular}{|c|c|c|c|c|c|}
\hline Strain & $\begin{array}{c}\text { Original } \\
\text { code }\end{array}$ & Species & $\begin{array}{c}\text { Num- } \\
\text { ber of } \\
\text { spores/g }\end{array}$ & $\begin{array}{l}\text { Number of } \\
\text { spores per dose } \\
\text { of inoculant }\end{array}$ & $\begin{array}{c}\text { Weight of } \\
\text { the inocu- } \\
\text { lant dose } \\
\text { (g) }\end{array}$ \\
\hline A92 & CNPAB 048 & $\begin{array}{l}\text { Acaulospora foveata Trappe \& Janos } \\
\text { (1982) }\end{array}$ & 7 & 10 & 1.43 \\
\hline A94 & CNPAB 050 & $\begin{array}{l}\text { Acaulospora mellea Spain \& N.C. } \\
\text { Schenck (1984) }\end{array}$ & 13 & 10 & 0.77 \\
\hline A96 & CNPAB 052 & $\begin{array}{l}\text { Acaulospora morrowiae Spain \& N.C. } \\
\text { Schenck (1984) }\end{array}$ & 23 & 10 & 0.43 \\
\hline A38 & IES-33 & $\begin{array}{l}\text { Acaulospora scrobiculata Trappe } \\
\text { (1977) }\end{array}$ & 43 & 10 & 0.23 \\
\hline
\end{tabular}


continuation

\begin{tabular}{|c|c|c|c|c|c|}
\hline A44 & Inoculum 51 & $\begin{array}{l}\text { Claroideoglomus etunicatum (W.N. } \\
\text { Becker \& Gerd.) C. Walker \& } \\
\text { Schuessler (2010) }\end{array}$ & 17 & 10 & 0.59 \\
\hline A2 & CNPAB 002 & $\begin{array}{l}\text { Dentiscutata heterogama (T.H. Nicol- } \\
\text { son \& Gerd.) Sieverd., F.A. Souza \& } \\
\text { Oehl (2008) }\end{array}$ & 23 & 10 & 0.43 \\
\hline A36 & IES-29 & $\begin{array}{l}\text { Gigaspora candida Bhattacharjee, } \\
\text { Mukerji, J.P. Tewari \& Skoropad } \\
\text { (1982) }\end{array}$ & 6 & 10 & 1.67 \\
\hline A20 & CNPAB 020 & $\begin{array}{l}\text { Glomus formosanum C.G. Wu \& Z.C. } \\
\text { Chen (1986) }\end{array}$ & 25 & 10 & 0.40 \\
\hline A5 & CNPAB 005 & $\begin{array}{l}\text { Rhizophagus clarus (T.H. Nicolson \& } \\
\text { N.C. Schenck) C. Walker \& Schuessler } \\
\text { (2010) }\end{array}$ & 8 & 10 & 1.25 \\
\hline A80 & CNPAB 038 & $\begin{array}{l}\text { Scutellospora calospora (T.H. Nicolson } \\
\text { \& Gerd.) C. Walker \& F.E. Sanders } \\
\text { (1986) }\end{array}$ & 15 & 10 & 0.67 \\
\hline \multirow[t]{2}{*}{ A75 } & CNPAB 034 & $\begin{array}{l}\text { Scutellospora gilmorei (Trappe \& } \\
\text { Gerd.) C. Walker \& F.E. Sanders } \\
\text { (1986) }\end{array}$ & 8 & 10 & 1.25 \\
\hline & & Inoculant mixture & 12 & 110 & 9.12 \\
\hline
\end{tabular}

The leaf area (LA) was estimated, and gas exchange was determined for the plants cultivated in 2017. The LA of green leaves was determined at the end of the production cycle using a LI-COR ${ }^{\circledR}$ meter leaf area meter (model LI 3100C) and expressed in square centimeters per plant. In December, gas exchange was determined using a LI-COR ${ }^{\circledR}$ infrared gas analyzer (IRGA) (model LI6400XT) (with

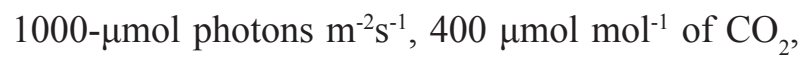
and $\Delta \mathrm{CO}_{2}+\Delta \mathrm{H}_{2} 0$ lower than $1 \%$ ) by measuring the net $\mathrm{CO}_{2}$ assimilation or photosynthetic performance $\left(A, \mu \mathrm{mol} \mathrm{CO} \mathrm{CO}_{2}^{-2} \mathrm{~s}^{-1}\right)$, stomatal conductance (gs, mol $\left.\mathrm{CO}_{2} \mathrm{~m}^{-2} \mathrm{~s}^{-1}\right)$, and transpiration rate $(E, \mathrm{mmol}$ $\mathrm{H}_{2} \mathrm{O} \mathrm{m}^{-2} \mathrm{~s}^{-1}$ ).

The data on the analyzed characteristics were tested for normality and homogeneity of the residuals using the Shapiro-Wilk and Hartley tests, respectively, and subjected to individual and joint analysis of variance. When the $\mathrm{F}$ test was significant, the means were subjected to Tukey's test at a level of significance of $5 \%$ and analyzed using the statistical program SISVAR version 5.3 (FERREIRA, 2010).

\section{Results and Discussion}

Production variables

There were no significant differences in the TNFP between the cultivars inoculated with AMF in 2016. However, this parameter was relatively higher in the cultivars Camarosa and San Andreas grown without AMF and in the cultivar Aromas grown with AMF (Table 3).

In 2017, in contrast to the previous year, the TNFP was higher in plants grown with AMF when compared with control plants. Moreover, this parameter was higher in the cultivars Monterey and Albion grown with or without AMF compared with the other cultivars (Table 3). In 2016, the CFY of AMF-treated plants from the cultivars Camino Real and Albion was higher than that of the respective controls. In the inoculated group, the mean CFY was higher in the cultivars Camarosa, Aromas, and Albion. In the control group, the mean CFY was higher in the cultivar Aromas (Table 3). 
In 2017, the mean CFY was higher in AMFtreated plants relative to untreated plants. The CFY was higher in the cultivar Albion inoculated or not with AMF relative to the other cultivars (Table 3). In 2016, the TFY was higher in the cultivars Camino Real and Albion treated with AMF than in the other treated cultivars. Furthermore, this variable was higher in the cultivar Camarosa treated with AMP and Aromas treated or not with AMF (Table 3).

In 2017, the TFY was higher in treated plants compared with the control groups and higher in plants from the cultivar Albion treated or not with AMF (Table 3). In 2016, there were no significant differences in the NCFY between the treated and control groups. Nonetheless, this parameter was significantly higher in the cultivar Camarosa (Table 3). In 2017, the NCFY was comparatively higher in inoculated plants. This variable was higher in the cultivars Albion and Monterey inoculated or not with AMF relative to the other cultivars.

The mean MWCFP in 2016 was higher in treated plants. This parameter was higher in the cultivars Albion and Camarosa inoculated with AMF compared with the respective controls. Furthermore, the MWCFP was higher in the cultivar Aromas treated or not with AMF when compared with the control (Table 3). In 2017, the MWCFP was higher in treated plants relative to control plants. This variable was higher in the cultivar Albion treated or not with AMF compared with the other cultivars.

The analysis of the production characteristics in 2016 indicated that AMF were effective, especially for the cultivars Camino Real and Albion, in which fruit yield in inoculated plants was higher than that in control plants, and the mean fruit yield in treated plants of the cultivar Camarosa was higher than that in control plants (Tables 3 and 4). In contrast to the results of 2016, in which AMF increased the yield of a few cultivars, the production characteristics of the inoculated cultivars were better in 2017 (Tables 3 and 4).
In 2017, edaphic-climatic conditions were different from those in 2016, with a longer dry period, which may have stimulated plant metabolism, allowing higher growth and development. Treatment with AMF may be beneficial to crops because the performance of these microorganisms is enhanced under environmental stress conditions. In 2016, there were no stress conditions in the evaluated crops, such as excessive radiation or high temperatures. This was characterized by mild temperatures, seasonal rains, and adequate relative humidity, allowing an increase in plant metabolism and precluding the need to allocate alternative energy resources for plant growth and development. Therefore, the improvement in production parameters by AMF was not as expected because these microorganisms are more active under stress conditions for the plant.

Bona et al. (2014) found that the fruit yield and size in strawberry plants inoculated with AMF was higher than that of control plants. This finding agrees with the present study because yield was augmented in treated plants in the two study years when compared with the respective controls. Castellanos-Morales et al. (2010) evaluated fruit yield and size in strawberry plants using different concentrations of nitrogen and inoculation of the AMF Rhizophagus intraradices and observed that the use of this fungus did not significantly affect these variables. This finding does not corroborate the present study because our results indicated that AMF increased fruit yield.

Nzanza et al. (2012) found that the weight of tomato fruits inoculated with mycorrhizae was higher than that of control plants. Similarly, Wang et al. (2008) observed that the weight of cucumber fruits was 1.4 and 1.3-fold higher in plants treated with F. mosseae or Glomus versiforme, respectively, than in the controls. These findings corroborate the present study, in which fruit yield was higher in AMF-treated plants. 
Martínez (2012) evaluated the quality and yield of the strawberry cultivars Albion and Jacona treated with the AMF Rhizophagus clarus and found that yield was increased by $28.75 \%$ in Albion relative to the control, and the mean fruit weight in inoculated plants of the Jacona cultivar was higher than that of the control. This finding agrees with the present study, in which AMF enhanced yield in the Albion cultivar by $31.87 \%$ in 2016 and $17.85 \%$ in 2017 relative to the control.

The production characteristics were better in the presence of AMF in the two study years.
Nonetheless, in 2017, these characteristics were improved in all inoculated cultivars. It is believed that treatment with AMF increases the uptake of minerals adsorbed to the soil, including phosphorus (SILVA, 2013), allowing higher yield in treated cultivars. This result may be due to the stressful environmental conditions in 2017, which enhanced the activity of AMFs and demonstrates that these microorganisms were effective in promoting plant growth and development.

The mean TNFP, CFY, NCFY, and TFY in 2016 and 2017 are shown in Table 3.

Table 3. Total number of fruits, yield of commercial and non-commercial fruits, and total fruit yield of strawberry cultivars grown with arbuscular mycorrhizal fungi at UNICENTRO, Guarapuava, Paraná, Brazil, in 2016 and 2017.

\begin{tabular}{|c|c|c|c|c|c|c|c|c|}
\hline \multicolumn{9}{|c|}{ Production parameters } \\
\hline \multicolumn{9}{|c|}{2016} \\
\hline & \multicolumn{2}{|c|}{ TNFP } & \multicolumn{2}{|c|}{ CFY } & \multicolumn{2}{|c|}{ NCFY } & \multicolumn{2}{|c|}{ TFY } \\
\hline \multirow[t]{2}{*}{ Cultivar } & \multicolumn{8}{|c|}{ Treatments } \\
\hline & I & NI & I & NI & I & NI & I & NI \\
\hline Camarosa & $69.44 \mathrm{aB}$ & $73.41 \mathrm{aA}$ & $1080.09 \mathrm{aA}$ & $1007.57 \mathrm{bA}$ & $87.90 \mathrm{aA}$ & $81.39 \mathrm{aA}$ & $1167.99 \mathrm{aA}$ & $1088.96 \mathrm{aB}$ \\
\hline Aromas & $68.60 \mathrm{aA}$ & $65.25 \mathrm{bB}$ & $1150.97 \mathrm{aA}$ & $1176.93 \mathrm{aA}$ & $79.87 \mathrm{aA}$ & $77.60 \mathrm{aA}$ & $1230.84 \mathrm{aA}$ & $1254.56 \mathrm{aA}$ \\
\hline Camino Real & $67.62 \mathrm{aA}$ & $66.03 \mathrm{bA}$ & $1051.53 \mathrm{bA}$ & $962.81 \mathrm{bB}$ & $70.29 \mathrm{aA}$ & $69.71 \mathrm{aA}$ & $1121.8 \mathrm{bA}$ & $1032.51 \mathrm{bB}$ \\
\hline Monterey & $68.84 \mathrm{aA}$ & $67.03 \mathrm{bA}$ & $947.26 \mathrm{bcA}$ & $883.93 \mathrm{bA}$ & $82.42 \mathrm{aA}$ & $87.84 \mathrm{aA}$ & $1029.68 \mathrm{bcA}$ & $971.77 \mathrm{bA}$ \\
\hline Portola & $66.00 \mathrm{aA}$ & $66.87 \mathrm{bA}$ & $909.13 \mathrm{cA}$ & $927.06 \mathrm{bA}$ & $71.67 \mathrm{aB}$ & $86.80 \mathrm{aA}$ & $980.80 \mathrm{cA}$ & $1013.85 \mathrm{bA}$ \\
\hline San andreas & $66.00 \mathrm{aB}$ & $69.53 \mathrm{bA}$ & $904.27 \mathrm{cA}$ & $902.64 \mathrm{bA}$ & $71.67 \mathrm{aB}$ & $89.37 \mathrm{aA}$ & $985.73 \mathrm{cA}$ & $992.011 \mathrm{bA}$ \\
\hline Albion & $66.43 \mathrm{aA}$ & $66.78 \mathrm{bA}$ & $1081.04 \mathrm{aA}$ & $704.29 \mathrm{cB}$ & $80.94 \mathrm{aB}$ & $87.37 \mathrm{aA}$ & $1161.98 \mathrm{bA}$ & $791.65 \mathrm{cB}$ \\
\hline Mean & $67.12 \mathrm{~A}$ & $67.41 \mathrm{~A}$ & $1017.7 \mathrm{~A}$ & $937.89 \mathrm{~B}$ & $77.83 \mathrm{~B}$ & $82.86 \mathrm{~A}$ & $1096.97 \mathrm{~A}$ & $1020.75 \mathrm{~B}$ \\
\hline CV (\%) & \multicolumn{3}{|c|}{3.11} & 6.1 & \multicolumn{2}{|c|}{12.21} & \multicolumn{2}{|c|}{5.84} \\
\hline \multicolumn{9}{|c|}{2017} \\
\hline Camarosa & $60.86 \mathrm{bA}$ & $57.36 \mathrm{bB}$ & $723.26 \mathrm{dA}$ & $553.36 \mathrm{~dB}$ & $73,18 \mathrm{aA}$ & $60.73 \mathrm{aB}$ & $890.94 \mathrm{cA}$ & $742.50 \mathrm{cB}$ \\
\hline Camino Real & $56.30 \mathrm{cA}$ & $51.27 \mathrm{cB}$ & $817.76 \mathrm{cA}$ & $681.76 \mathrm{cB}$ & $73.71 \mathrm{aA}$ & $60.86 \mathrm{aB}$ & $796.97 \mathrm{dA}$ & $614.22 \mathrm{~dB}$ \\
\hline Monterey & $66.24 \mathrm{aA}$ & $62.74 \mathrm{aB}$ & $1019.21 \mathrm{bA}$ & $795.63 \mathrm{bB}$ & $84.02 \mathrm{aA}$ & $67.91 \mathrm{aB}$ & $1103.24 \mathrm{bA}$ & $863.54 \mathrm{bB}$ \\
\hline Albion & $67.11 \mathrm{aA}$ & $62.88 \mathrm{aB}$ & $1062.62 \mathrm{aA}$ & $880.53 \mathrm{aB}$ & $91.62 \mathrm{aA}$ & $67.77 \mathrm{aB}$ & $1154.24 \mathrm{aA}$ & $948.30 \mathrm{aB}$ \\
\hline Mean & $62.63 \mathrm{~A}$ & $58.56 \mathrm{~B}$ & $905.71 \mathrm{~A}$ & $727.82 \mathrm{~B}$ & $80.63 \mathrm{~A}$ & $64.32 \mathrm{~B}$ & $986.35 \mathrm{~A}$ & $792.14 \mathrm{~B}$ \\
\hline CV (\%) & & 1.6 & & 2.18 & $7 .($ & & & 2.06 \\
\hline
\end{tabular}

I, inoculated; NI, not inoculated; TNFP, total number of fruits per plant; CFYP, commercial fruit yield (g/plant); NCFYP, noncommercial fruit yield (g/plant); TFYP, total fruit yield (g/plant); CV, coefficient of variation. The results are presented as mean $(n=7$ and $n=4)$. Means with the same lowercase letters in each column and the same uppercase letters in each line were not significantly different from each other using the Tukey's test $(\mathrm{p} \leq 0.05)$.

The NCFP, NNCFP, and MWCFP in 2016 and 2017 are shown in Table 4. 
Table 4. Number of commercial and non-commercial fruits and mean weight of commercial fruits in strawberry plants treated with arbuscular mycorrhizal fungi at UNICENTRO, Guarapuava, Paraná, Brazil, in 2016 and 2017.

\begin{tabular}{|c|c|c|c|c|c|c|}
\hline \multicolumn{7}{|c|}{ Production parameters } \\
\hline \multicolumn{7}{|c|}{2016} \\
\hline & \multicolumn{2}{|c|}{ NCFP } & \multicolumn{2}{|c|}{ NNCFP } & \multicolumn{2}{|c|}{ MWCFP } \\
\hline Cultivar & I & NI & I & NI & I & NI \\
\hline Camarosa & $58.72 \mathrm{aB}$ & $62.15 \mathrm{aA}$ & $11.62 \mathrm{aA}$ & $11.25 \mathrm{aA}$ & $18.36 \mathrm{bcA}$ & $16.21 \mathrm{bB}$ \\
\hline Aromas & $55.97 \mathrm{abA}$ & $54.50 \mathrm{bA}$ & $12.72 \mathrm{aA}$ & $10.75 \mathrm{aA}$ & $20.58 \mathrm{aA}$ & $21.59 \mathrm{aA}$ \\
\hline Camino Real & 56.81abA & $55.69 \mathrm{bA}$ & $10.81 \mathrm{aA}$ & $10.34 \mathrm{aA}$ & $18.50 \mathrm{bcA}$ & $17.28 \mathrm{bA}$ \\
\hline Monterey & $55.44 \mathrm{abA}$ & $55.34 \mathrm{bA}$ & $13.40 \mathrm{aA}$ & $11.69 \mathrm{aA}$ & $17.08 \mathrm{cdA}$ & $15.97 \mathrm{bA}$ \\
\hline Portola & $55.37 \mathrm{bA}$ & $54.50 \mathrm{bA}$ & $10.62 \mathrm{aA}$ & $12.37 \mathrm{aA}$ & $16.39 \mathrm{dA}$ & $17.01 \mathrm{bA}$ \\
\hline San Andreas & $54.94 \mathrm{bA}$ & $57.28 \mathrm{bA}$ & $11.06 \mathrm{aA}$ & $12.25 \mathrm{aA}$ & $16.45 \mathrm{dA}$ & $15.74 \mathrm{bA}$ \\
\hline Albion & $55.34 \mathrm{abA}$ & $54.00 \mathrm{bA}$ & $11.09 \mathrm{aA}$ & $12.78 \mathrm{aA}$ & $19.53 \mathrm{bA}$ & $13.04 \mathrm{cB}$ \\
\hline Mean & $56.08 \mathrm{~A}$ & $56.21 \mathrm{~A}$ & $11.62 \mathrm{~A}$ & $11.63 \mathrm{~A}$ & $18.13 \mathrm{~A}$ & 16.69B \\
\hline CV (\%) & \multicolumn{2}{|r|}{3.05} & & 12.06 & \multicolumn{2}{|c|}{4.84} \\
\hline \multicolumn{7}{|c|}{2017} \\
\hline Camarosa & $50.16 \mathrm{bA}$ & $47.52 \mathrm{bB}$ & $10.24 \mathrm{bA}$ & $9.66 \mathrm{aB}$ & $16.29 \mathrm{cA}$ & $14.34 \mathrm{cB}$ \\
\hline Camino Real & $46.05 \mathrm{cA}$ & $41.61 \mathrm{cB}$ & $10.63 \mathrm{bA}$ & $9.83 \mathrm{aA}$ & $15.70 \mathrm{dA}$ & $13.29 \mathrm{~dB}$ \\
\hline Monterey & $55.61 \mathrm{aA}$ & $53.58 \mathrm{aB}$ & $10.69 \mathrm{bA}$ & $10.16 \mathrm{aA}$ & $18.32 \mathrm{bA}$ & $15.13 \mathrm{bB}$ \\
\hline Albion & $55.27 \mathrm{aA}$ & $52.30 \mathrm{aB}$ & $11.83 \mathrm{aA}$ & $10.58 \mathrm{aB}$ & $19.22 \mathrm{aA}$ & $16.83 \mathrm{aB}$ \\
\hline Mean & $51.77 \mathrm{~A}$ & $48.50 \mathrm{~B}$ & $10.85 \mathrm{~A}$ & $10.06 \mathrm{~B}$ & $17.38 \mathrm{~A}$ & $14.90 \mathrm{~B}$ \\
\hline CV (\%) & & 1.52 & & 5.93 & & 1.22 \\
\hline
\end{tabular}

I, inoculated with mycorrhizal fungi; NI, not inoculated with mycorrhizal fungi; NCFP, number of commercial fruits per plant; NNCFP, number of non-commercial fruits per plant; MWCFP, mean weight of commercial fruits per plant (g); CV, coefficient of variation. The results are presented as mean $(n=7$ and $n=4)$. Means with the same lowercase letters in each column and the same uppercase letters in each line were not significantly different from each other using the Tukey's test $(\mathrm{p} \leq 0.05)$.

\section{Leaf area}

In 2017, there was a significant difference in LA between strawberry cultivars grown with and without AMF. Moreover, there were significant differences in individual parameters between cultivars grown in the presence and absence of AMF. LA was higher in inoculated cultivars than in controls. The differences were significant for all cultivars, except for Albion (Table 5).

LA was higher in treated plants of the cultivar Camarosa and lower in treated plants of the cultivar Albion relative to the other treated cultivars. There were no significant differences in LA between the untreated cultivars (Table 5).
There was a significant increase in LA by $380 \%$, $207 \%, 220 \%$, and $68 \%$ in the inoculated cultivars Camarosa, Camino Real, Monterey, and Albion, respectively, compared with the respective controls. Despite the higher LA with AMF, there were no significant differences in this variable in the cultivar Albion treated or not with AMF.

The larger LA increases the photosynthetic area, enhancing sunlight absorption and energy efficiency (carbohydrate synthesis) for plant growth and development, resulting in the production of larger fruits. 
Table 5. Leaf area of strawberry cultivars treated with mycorrhizal fungi at UNICENTRO, Guarapuava, Paraná, Brazil, in 2017.

\begin{tabular}{lcc}
\hline & \multicolumn{2}{c}{ Leaf area $\left(\mathrm{cm}^{2}\right)$} \\
\hline Camarosa & Inoculated & Uninoculated \\
Camino Real & $5230.30 \mathrm{aA}$ & $1429.36 \mathrm{aB}$ \\
Monterey & $4028.33 \mathrm{abA}$ & $1946.40 \mathrm{aB}$ \\
Albion & $2760.51 \mathrm{bcA}$ & $1246.89 \mathrm{aB}$ \\
Mean & $1710.02 \mathrm{cA}$ & $1162.51 \mathrm{aA}$ \\
\hline CV $(\%)$ & $3432.29 \mathrm{~A}$ & $1448.29 \mathrm{~B}$ \\
\hline
\end{tabular}

$\mathrm{CV}$, coefficient of variation. The results are presented as mean $(n=6)$. Means with the same lowercase letters in each column and the same uppercase letters in each line were not significantly different from each other using the Tukey's test ( $\mathrm{p} \leq 0.05)$.

LA is a relevant characteristic because it is related to the rate of photosynthesis carried out by the plant and affects the production of photoassimilates, which are partially translocated to the AMF and fruits (CAVALCANTE et al., 2002). Silva et al. (2004) observed that the larger LA in plants treated with AMF was positively correlated with higher $A$, leading to augmented plant growth and biomass.

The expansion of LA by AMF in different strawberry cultivars agrees with the results obtained for other crops, including acerola (Costa et al., 2001), passion fruit (Cavalcante et al., 2002), mangaba (Costa et al., 2005), and papaya (Lima et al., 2011). These studies found that the LA of AMF-treated plants was larger than that of untreated plants.

\section{Gas exchange}

The net $\mathrm{CO}_{2}$ assimilation $(A)$ in the cultivars Camarosa and Camino Real inoculated with AMF was higher than that of the controls. In contrast, $A$ was higher in untreated plants from cultivars Monterey and Albion. Moreover, $A$ was higher in the latter two cultivars (neutral day cultivars) compared with short-day cultivars (Table 6). This result may be because Monterey and Albion are insensitive to the photoperiod and, at the time of data analysis (December), were in full production, whereas the cultivars Camarosa and Camino Real are short-lived and, therefore, have lower biological activity.

$A$ was increased in the cultivars Camarosa and Camino Real inoculated with AMF (Table 6), which may justify the results on fruit yield in these cultivars because higher $A$ results in higher yield. This result demonstrates the effectiveness of inoculation in these cultivars.

The comparatively higher $A$ in these two cultivars may be related to improved physiological function provided by the symbiotic association. However, the mechanisms by which mycorrhization causes these beneficial effects on gas exchange are not yet fully understood (SHENG et al., 2008).

There were no significant differences in $g s$ between the treatments. However, in the AMFtreated group, the cultivar with the highest and lowest mean gs was Monterey and Camino Real, respectively. In the control group, gs was relatively higher in the cultivar Monterey and lower in the cultivars Camarosa and Camino Real, with no significant difference between the latter two (Table 6).

There were no significant differences in $E$ between the treatments. However, $E$ was higher in the inoculated plants from the Camarosa cultivar compared with untreated plants. 
Among the treated plants, $E$ was higher in the cultivars Monterey and Camarosa and lower in the cultivars Albion and Camino Real, without significant difference between the latter two cultivars. In untreated plants, $E$ was higher in the cultivar Monterey and lower in the cultivars Albion, Camarosa, and Camino Real, with no significant differences between the last three cultivars (Table 6).

Rosa (2016) evaluated physiological changes in vines inoculated with Dentiscutata heterogama and found that the rate of $\mathrm{CO}_{2}$ assimilation, $g s$, and $E$ were higher in AMF-treated plants. In the present study, the rate of $\mathrm{CO}_{2}$ assimilation was relatively higher in the cultivars Camarosa and Camino Real, corroborating the results of previous studies.

$A$ and $E$ were higher in inoculated cultivars, with higher $A$ in the cultivars Camarosa and Camino Real and higher $E$ in the cultivars Camarosa and
Monterey, without significant differences between the latter two cultivars. This result may be due to higher water and mineral absorption caused by AMF.

This result is justified by the obligatory symbiosis, which requires the plant to provide glucose and fructose to the hyphae, allowing the total energy cost of carbohydrate production to reach up to $20 \%$ of photosynthesis production (BOLDT et al., 2011; ADOLFSSON et al., 2015). As a result, the plant increases $\mathrm{CO}_{2}$ assimilation to compensate for the need for carbohydrates, ensuring continuity of symbiosis and benefiting from the improved nutrition provided by mycorrhizae (ADOLFSSON et al., 2015).

The mean gas exchange of strawberry cultivars cultivated with and without AMF are shown in Table 6.

Table 6. Results of physiological parameters of strawberry cultivars grown with arbuscular mycorrhizal fungi at UNICENTRO, Guarapuava, Paraná, Brazil, in 2017.

\begin{tabular}{lcccccc}
\hline Cultivar & \multicolumn{2}{c}{$A\left(\mu \mathrm{mol} \mathrm{CO}_{2} \mathrm{~m}^{-2} \mathrm{~s}^{-1}\right)$} & \multicolumn{2}{c}{$g s\left(\mathrm{~mol} \mathrm{CO}_{2} \mathrm{~m}^{-2} \mathrm{~s}^{-1}\right)$} & \multicolumn{2}{c}{$E\left(\mathrm{mmol} \mathrm{H}_{2} \mathrm{O} \mathrm{m}^{-2} \mathrm{~s}^{-1}\right)$} \\
\hline Camarosa & $\mathrm{I}$ & $\mathrm{NI}$ & $\mathrm{I}$ & $\mathrm{NI}$ & $\mathrm{I}$ & $\mathrm{NI}$ \\
Camino Real & $6.88 \mathrm{bA}$ & $5.42 \mathrm{bB}$ & $0.68 \mathrm{abA}$ & $0.60 \mathrm{bA}$ & $8.58 \mathrm{aA}$ & $7.77 \mathrm{bB}$ \\
Albion & $7.13 \mathrm{bA}$ & $5.73 \mathrm{bB}$ & $0.60 \mathrm{bA}$ & $0.60 \mathrm{bA}$ & $7.51 \mathrm{bA}$ & $7.71 \mathrm{bA}$ \\
Monterrey & $6.51 \mathrm{aB}$ & $7.85 \mathrm{aA}$ & $0.65 \mathrm{abA}$ & $0.69 \mathrm{abA}$ & $7.69 \mathrm{bA}$ & $8.22 \mathrm{bA}$ \\
Mean & $6.99 \mathrm{aB}$ & $7.56 \mathrm{aA}$ & $0.80 \mathrm{aA}$ & $0.81 \mathrm{aA}$ & $9.12 \mathrm{aA}$ & $9.49 \mathrm{aA}$ \\
\hline CV (\%) & $6.88 \mathrm{~A}$ & $6.64 \mathrm{~A}$ & $0.68 \mathrm{~A}$ & $0.68 \mathrm{~A}$ & $8.23 \mathrm{~A}$ & $8.29 \mathrm{~A}$ \\
\hline
\end{tabular}

I, inoculated with mycorrhizal fungi; NI, not inoculated with mycorrhizal fungi, $A$, photosynthetic performance; gs, stomatal conductance; $E$, transpiration rate; $\mathrm{CV}$, coefficient of variation. The results are presented as mean $(\mathrm{n}=6)$. Means with the same lowercase letters in each column and the same uppercase letters in each line were not significantly different from each other using the Tukey's test $(\mathrm{p} \leq 0.05)$.

\section{Conclusion}

The present results demonstrated that rhizospheric microorganisms significantly improved production and physiological parameters of strawberry cultivars in the two study years. Therefore, this treatment strategy can reduce the use of fertilizers and increase agricultural sustainability.

\section{Acknowledgments}

To Capes for providing a masters scholarship to the first author; to the Araucária Foundation and $\mathrm{CNPq}$ for funding this research; and to Embrapa Agrobiology for providing mycorrhizal fungi. 


\section{References}

ADOLFSSON, L.; SOLYMOSI, K.; ANDERSSON, M. X.; KERESZTES, A. Mycorrhiza symbiosis increases the surface for sunlight capture in Medicago truncatula for better photosynthetic production. Plos One, v. 10, n. 1, p. 1-18, 2015. DOI: 10.1371/journal.pone.0115314

ALARCÓN, A.; CERRATO, R. F.; CHAVÉZ, M. C. G.; MONTER, A. V. Hongos micorrizicos arbusculares en la dinámica de aparición de estolones y nutrición de plantas de fresa Cv. Obtenidas por cultivo in vitro. Terra, v. 18, n. 3 , p. $211-218,2000$.

ANTUNES, P.; FRANKEN, P.; SCHWARZ, D.; RILliG, M. C.; COSME, M.; SCOTT, M.; HART, M. M. Linking soil biodiversity and human health: do arbuscular mycorrhizal fungi contribute to food nutrition. In: WALL, D. H.; BARDGETT, R. D.; BEHANPELLETIER, V.; HERRICK, J. E.; JONES, T. H.; RITZ, K.; SIX, J.; STRONG, D. R.; VAN DER PUTTEN, W. H. Soil ecology and ecosystem services. New York: Oxford University Press, 2012. p. 153-172.

BOLDT, K.; PÖRS, Y.; HAUPT, B.; BITTERLICH, M, C.; GRIMM, B.; FRANKEN, P. Photochemical processes, carbon assimilation and RNA accumulation of sucrose transporter genes in tomato arbuscular mycorrhiza. Journal of Plant Physiology, v. 168, n. 1, p. 1256-1263, 2011. DOI: 10.1016/j.jplph.2011.01.026

BONA, E.; LÍNGUA, G.; MANASSERO, P.; CANTAMESSA, S.; MARSANO, F.; TODESCHINI, V.; COPETTA, A.; D’AgOSTINO, G.; MASSA, N.; AVIDANO, L.; GAMALERO, E.; BERTA, G. AM fungi and PGP pseudomonads increase flowering, fruit production, and vitamin content in strawberry grown at low nitrogen and phosphorus levels. Mycorrhiza, v. 25, n. 3, p. 181-193, 2014. DOI: 10.1007/s00572-014-0599-y

BORKOWSKA, B. Growth and photosynthetic activity of micropropagated strawberry plants inoculated with endomycorrhizal fungi (AMF) and growing under drought stress. Acta Physiologiae Plantarum, v. 24, n. 4, p. 365-370, 2002. DOI: 10.1007/s11738-002-0031-7

BOROWICZ, V.A. The impact of arbuscular mycorrhizal fungi on strawberry tolerance to root damage and drought stress. Pedobiologia, New York, v. 53, n. 4, p. 265-270, 2010. DOI: 10.1016/j.pedobi.2010.01.001

CASTELLANOS-MORALES, V.; VILLEGAS, J.; WENDELIN, S.; VIERHEILIG, H.; EDER, R.; CÁRDENAS-NAVARRO, R. Root colonisation by the arbuscular mycorrhizal fungus Glomus intraradices alters the quality of strawberry fruits (Fragaria $x$ ananassa Duch.) at different nitrogen levels. Journal of the Science of Food and Agriculture, v. 90, n. 11, p. 1774-1782, 2010. DOI: $10.1002 /$ jsfa.3998
CAVAlCANTE, U. M. T.; MAIA, L. C.; COSTA, C. M. C.; CAVALCANTE, A. T.; SANTOS, V. F. Efeito de fungos micorrízicos arbusculares, da adubação fosfatada e da esterilização do solo no crescimento de mudas de maracujazeiro amarelo. Revista Brasileira de Ciências do Solo, v. 26, n. 4, p. 1099-1106, 2002. DOI: 10.1590/ s0100-06832002000400028

CECATTO, A.P.; RUIZ, F. M.; CALVETE, E. O.; MARTÍNEZ, J.; PALENCIA, P. Mycorrhizal inoculation affects the phytochemical contente in strawberry fruits. Acta Scientiarum, v. 38, n. 2, p. 227-237, 2016. DOI: 10.4025/actasciagron.v38i2.27932

COSCOLIN, R. B. S. Plantas de amendoim (Arachis hypogaea L.) submetida à deficiência hídrica e a influência da associação com fungos micorrízicos arbusculares e extratos de algas marinhas. 2016. Tese (Doutorado em Ciências Agronômicas) - Universidade Estadual de São Paulo, São Paulo.

COSTA, C. M. C.; CAVALCANTE, U. M. T.; GOTO, B. T.; SANTOS, V. F.; MAIA, L. C. Fungos micorrízicos arbusculares e adubação fosfatada em mudas de mangabeira. Pesquisa Agropecuária Brasileira, v.40, n. 3, p. 225-232, 2005. DOI: 10.1590/s0100204x2005000300005

COSTA, C. M. C.; MAIA, L. C.; CAVALCANTE, U. M. T.; NOGUEIRA, R. J. M. C. Influência de fungos micorrízicos arbusculares sobre o crescimento de dois genótipos de aceroleira (Malpighia emarginata D.C.). Pesquisa Agropecuária Brasileira, v. 36, n. 6, p.893-901, 2001. DOI: $10.1590 / \mathrm{S} 0100-204 X 2001000600007$

EMPRESA BRASILEIRA DE PESQUISA AGROPECUÁRIA - EMBRAPA. Sistema Brasileiro de Classificação de Solos. 3. ed. Brasília: EMBRAPA Solos: 2013. 286 p.

FERREIRA, D. F. SISVAR: sistema de análise de variância. Versão 5.3. Lavras, MG: UFLA, 2010.

FOOD AGRICULTURAL ORGANIZATION - FAO. FAOSTAT - Agriculture. Guarapuava: FAO, 2014. Disponível em: http://faostat3.fao.org/. Acesso em 4 set. 2017.

GIMÉNEZ, G.; ANDRIOLO, J. L.; GODOI, R. S. Cultivo sem solo do morangueiro. Ciência Rural, v. 38, n. 1, p. 273279, 2008. DOI: 10.1590/S0103-84782008000100048

KIRSCHBAUM, D. S.; BORQUEZ, A. M. Nutrición mineral de la frutilla (Fragaria $x$ ananassa Duch.). In: SIMPÓSIO NACIONAL DO MORANGO, 3.; ENCONTRO SOBRE PEQUENAS FRUTAS E FRUTAS NATIVAS DO MERCOSUL, 2., Pelotas, 2006. Palestras... Pelotas: Embrapa Clima Temperado, 2006. p. 117-127. 
LIMA, K. B.; MARTINS, M. A.; FREITAS, M. S. M.; OLIVARES, F. L. Fungos micorrízicos arbusculares, bactérias diazotróficas e adubação fosfatada em mudas de mamoeiro. Revista Brasileira de Fruticultura, Jaboticabal, v. 33, n. 3, p. 932-940, 2011. DOI: 10.1590/ s0100-29452011000300029

MARTÍNEZ, L. F. S. Calidad y Rendimiento de Fresa Inoculada con Hongos Micorrízicos Arbusculares. 2012. Disertatión (Maestría en Ciencias en Producción Agrícola Sustentable) - Instituto Politécnico Nacional, Colegio de Profesores de Estudios de Posgrado e Investigación, Jiquilpan Mich.

MATSUBARA, Y.; ISHIGAKI, T.; KOSHIKAWA, $\mathrm{K}$. Changes in free amino acid concentrations in mycorrhizal strawberry plants. Scientia Horticulturae, New York, v. 119, n. 4, p. 392-396, 2009. DOI: 10.1016/j. scienta.2008.08.025

NIEMI, M. Y.; VESTBERG, M. Inoculation of commercially grown strawberry with VA mycorrhizal fungi. Plant and Soil, v.144, n. 1, p.133-142, 1992. DOI: $10.2307 / 42938108$

NZANZA, B., MARAIS, D., SOUNDY, P. Response of tomato (Solanum lycopersicum L.) to nursery inoculation with Trichoderma harzianum and arbuscular mycorrhizal fungi under field conditions. Acta, Agriculturae. Scandinavica, Section B - Soil and plant Science. $B-S$ P, v. 62 , n. 3, p. 209-215, 2012. DOI: 10.1080/09064710.2011.598544

REISSER JÚNIOR, C.; ANTUNES, L. E. C.; ALDRIGHI, M.; VIGNOLO, G. Panorama do cultivo de morangos no Brasil. Revista Campo e Negócios, p. 5859, 2014. Disponível em: http://ainfo.cnptia.embrapa. br/ digital/bitstream/item/116016/1/CampoNegocio-DEZ2014-Panorama.pdf. Acesso em: 09 apr. 2019.

ROSA, D. J.; AMBROSINI, V. G.; BRUNETTO, G.; SOARES, C. R. F. S.; BORGHEZAN, M.; PESCADOR, R. Parâmetros fisiológicos em videiras 'Pausen 1103' (Vitis berlandieri $x$ Vitis rupestris) inoculadas com fungos micorrízicos arbusculares em solo contaminado com cobre. Ciência e Técnica Vitivinícola, v. 31, n. 1, p. 14-23, 2016. DOI: $10.1051 / \mathrm{ctv} / 20163101014$

ROUPHAEL, Y.; FRANKEN, P.; SCHNEIDER, C.; SCHWARZ, D.; GIOVANNETTI, M.; AGNOLUCCI, M.; PASCALEA, S. D.; BONINIF, P.; COLLA, G. Arbuscular mycorrhizal fungi act as biostimulants in horticultural crops. Scientia Horticulturae, v. 196, n. 1, p. 91-108, 2015. DOI: 10.1016/j.scienta.2015.09.002
SAGGIN JÚNIOR, O. J.; SILVA, E. M. R. Micorriza arbuscular- papel, funcionamento e aplicação da simbiose. In: AQUINO, A. M. de.; ASSIS, R. L. de. (Org.). Processos biológicos do sistema solo planta ferramentas para uma agricultura sustentável. Brasília: Embrapa Agrobiologia, Embrapa Informação Tecnológica, v. 1, 2005. p. 101-149.

SHENG, M.; TANG, M.; CHEN, H.; YANG, B.; ZHANG, F.; HUANG, Y. Influence of arbuscular mycorrhizae on photosynthesis and water status of maize plants under salt stress. Mycorrhiza, v. 18, n. 6-7, p. 287-296, 2008. DOI: $10.1007 / \mathrm{s} 00572-008-0180-7$

SILVA, M. A.; CAVALCANTE, U. M. T.; SILVA, F. S.B.; SOARES, S. A. G.; MAIA, L. C. Crescimento de mudas de maracujazeiro-doce (Passiflora alata Curtis) associadas a fungos micorrízicos arbusculares (Glomeromycota). Acta Botânica Brasílica, São Paulo, v. 18 , n. 4 , p. $981-985,2004$. DOI: $10.1590 / \mathrm{s} 0102-$ 33062004000400028

SILVA, M. L. S.; RESENDE J. T. V.; TREVISAM, A. R.; FIGUEIREDO, A. S. T.; SCHWARZ, K. Influência do Silício na produção e qualidade de frutos do morangueiro. Semina: Ciências Agrárias, Londrina, v. 34, n. 6, p. 3411-3424, 2013. DOI: 10.5433/1679-0359.2013v34n6Supl1p3411

SMITH, S. E.; READ, D. J. Mycorrhizal symbiosis. Califórnia: Academic Press, 2008. 605 p.

VESTBERG， M.; KUKKONEN， S.; SAARI，K.; PARIKKA, P.; HUTTUNEN, C.; TAINIO, L.; DEVOS, N.; WEEKWERS, F.; KEVERS, C.; THONART, P.; LEMOINE, M. C.; CORDIERF, C.; ALABOUVETTE, C.; GIANINAZZI, S. Microbial inoculation for improving the growth and health of micropropagated strawberry. Applied Soil Ecology, v. 27, n. 3, p. 243-258, 2004. DOI: 10.1016/j.apsoil.2004.05.006

VOS, C.; VAN DEN BROUCKE, D.; LOMBI, F. M.; WAELE, D. de; ELSEN, A. Mycorrhiza-induced resistance in banana acts on nematode host location and penetration. Soil Biology and Biochemistry, New York, v. 47, n. 1, p. 60-66, 2012. 605 p. DOI: 10.1016/j. soilbio.2011.12.027

WANG, C.; LI, X.; ZHOU, J.; WANG, G.; DONG, Y. Effects of arbuscular mycorrhizal fungi on growth and yield of cucumber plants. Communications in Soil Science and Plant Analysis, v. 39, n. 3-4, p. 499-509, 2008. DOI: $10.1080 / 00103620701826738$ 